University of Massachusetts Amherst

ScholarWorks@UMass Amherst

2018

\title{
Criticality in international higher education research: A critical discourse analysis of higher education journals
}

\author{
Chrystal A. George Mwangi \\ University of Massachusetts Amherst \\ Sadaf Latafat \\ University of Massachusetts Amherst \\ Shane P. Hammond \\ Suzan Kommers \\ University of Massachusetts Amherst \\ Hanni Thoma \\ University of Massachusetts Amherst
}

See next page for additional authors

Follow this and additional works at: https://scholarworks.umass.edu/cfssr_publishedwork

\section{Recommended Citation}

George Mwangi, Chrystal A.; Latafat, Sadaf; Hammond, Shane P.; Kommers, Suzan; Thoma, Hanni; Berger, Joseph B.; and Blanco-Ramirez, Gerardo, "Criticality in international higher education research: A critical discourse analysis of higher education journals" (2018). Higher Education. 27.

https://doi.org/10.1007/s10734-018-0259-9

This Article is brought to you for free and open access by the Center for Student Success Research at ScholarWorks@UMass Amherst. It has been accepted for inclusion in Published Work by an authorized administrator of ScholarWorks@UMass Amherst. For more information, please contact scholarworks@library.umass.edu. 


\section{Authors}

Chrystal A. George Mwangi, Sadaf Latafat, Shane P. Hammond, Suzan Kommers, Hanni Thoma, Joseph B. Berger, and Gerardo Blanco-Ramirez 
Criticality in international higher education research: A critical discourse analysis of higher education journals

\author{
Chrystal A. George Mwangi \\ Sadaf Latafat
}

Shane Hammond

Suzan Kommers

Hanni Thoma

Joseph Berger

University of Massachusetts Boston

Gerardo Blanco-Ramirez

University of Massachusetts Boston

For the published version of this article, please visit:

George Mwangi, C. A., Latafat, S., Hammond, S., Kommers, S., Thoma, H., Berger, J. \& Blanco-Ramirez, G. (2018). Criticality in international higher education research: A critical discourse analysis of higher education journals. Higher Education, 76(6), 10911107. 
The global study of higher education appears to be experiencing a paradox. On one hand, there is growing research on internationalization efforts of college campuses, comparative studies, a focus on non-Western nations, and an emphasis on the impact of globalization on higher education (Tight 2012b). Yet, scholars have also admonished research related to international higher education for having a narrowed Western scope and reinforcing methodological nationalism (Shahjahan and Kezar 2013; Tight 2014). We argue that academic journals are at the center of this paradox because of their role in knowledge dissemination. The purpose of this study is to examine discourses that are created by higher education journals regarding internationalization within the field. We ask the research questions: How are discourses on international higher education and internationalization in higher education presented in higher education journals? What discourses of criticality are present or absent regarding international higher education and internationalization in higher education?

\section{Critical Paradigm}

This study utilizes a critical paradigm to investigate research on internationalization in higher education. Criticality as a theoretical worldview emphasizes the deconstruction and critique of social institutions as well as the transformation of institutions and emancipation of people for the outcome of social justice (Crotty 1998). This paradigm defines reality and knowledge as socially constructed entities influenced by political, historical, cultural, and economic factors as well as societal power relations (Guba and Lincoln 1994). A tenet of the critical worldview is that knowledge is not value free or objective, meaning that research inquiry reflects researchers' social positioning, values, and agenda (Pring 2000). Critical research promotes transforming the status quo, rectifying injustices and inequities, and understanding power relations to illuminate oppression, exploitation, and marginalization (Crotty 1998; Giroux 
2011).

Our study examines whether and how a critical orientation is addressed in contemporary research on international higher education. We recognize the multiplicity of approaches that can be included under the "critical" label (Baez, 2007). While this term may be contested, some form of conceptual operationalization is necessary. Consequently, our focus is on whether issues of inequality are explicitly articulated, how power differences are addressed, and whether an emancipatory agenda or the interruption of oppression is explicitly discussed (Crotty, 1998; Baez, 2007). The question of criticality is central to comparative and international higher education. As Tikly and Bond (2013) explained, in the context of international education research, criticality is manifested through explicit references to colonialism and by an alignment with postcolonial and decolonial thought. From this perspective, critical research entails not only acknowledging the impact of colonization but, most importantly, providing a critique of how knowledge production and academic standards normalize and reinforce Western oppression and ways of knowing (Stein and Andreotti, 2017). Without this intentionality, higher education researchers and journals fail to recognize the implicit and embedded values assessment within processes deemed neutral in the pursuit of empirical knowledge development and dissemination. Through critical discourse analysis, we explore the orientation of higher education research towards equity and inclusivity and challenge the perception of international higher education research and its distribution through academic journals as values neutral.

\section{Literature Review}

Several articles have explored research production among scholars of international education. Among these studies it is possible to identify two clusters. The first includes 
bibliography-based approaches with a main focus on international education. The second comprises studies aimed at identifying general trends or establishing the state of the field.

\section{Bibliography-based Studies}

While peer-reviewed studies of research production are limited, those on international higher education are even scarcer. There are two articles (Raby 2007; Easton 2014) that focus on a bibliographic approach to single journal analysis.

Raby (2007) analyzed 50 years of annual bibliographies for Comparative Education Review (CER). The analysis reviewed trends over time organized by five thematic elements: “(a) changing structure of bibliographies over time, (b) devaluation of theoretical/methodological articles, (c) change in geographical regions, (d) thematic representation, and (e) unique features of the 2006 bibliography" (Raby 2007, 379-380). This analysis was not focused on higher education literature, but on the broader field of comparative and international education.

Raby (2007) found there was a decline in the number of articles focused on theory and/or methodology. There has also been a growth in the number of geographic regions emphasized, but this growth has been uneven in coverage. The trends have been reflective of larger sociohistorical and geopolitical concerns. For example, the Soviet Union was a bigger focus in the 1960s and 1970s, whereas the Middle East and North Africa has grown in recent years. This is important given that broader contexts do influence choices of where to study, what to study, what gets funded, and what gets published; yet, there has been little critical analysis of these trends. Raby (2007) also looked at a variety of themes that were largely value-neutral. However, she did identify studies that focused on issues such as gender, race, ethnicity, class, religion, and sexuality. These areas potentially indicate a less values-neutral approach to scholarship, but there was no deeper analysis other than a descriptive count of types of articles. 
Easton (2014) also reviewed CER bibliographies to define what is included and what the criteria for inclusion are or should be. His analysis revealed a broadening of scope over time and an over-emphasis on Europe and Russia in geographic coverage. From 1979 to 2013, articles on Europe and Russia accounted for over one-third of all articles, with no other region approaching half that number. Easton noted that new categories have grown rapidly, including gender and sexuality, ethnicity, race, and class. However, he did not evaluate what value orientation or paradigm informed these studies.

\section{General Trends Studies}

Tight (2007) compared research published in English language journals focusing on North American journals (U.S. and Canada) and non-North American sources. Tight (2007) identified that very few studies published in the North American journals had an international focus. He made the observation, "North American higher education researchers (but most particularly those based in the United States) tend to write without reference to anything - policy, experience, publications - coming from outside North America” (Tight 2007, 247). This observation provides support to the rationale for conducting the present study.

In a study comparing international higher education journals in 2000 and 2010, Tight (2012a) identified that in 2000, the number of internationally-oriented studies was $6 \%$. However, in the 2010 sample this percentage doubled. Tight identified that higher education research was going through a rapid process of internationalization, even though this was primarily evident in non-North American journals. In a different study, Tight (2013) focused on theoretical and methodological approaches in higher education research. Tight identified that North American journals tend to publish studies focused on student experiences relying on multivariate 
quantitative methods. On the other hand, internationally-oriented studies tend to focus on policy and generally rely on document analysis.

The studies discussed demonstrate a significant divide between North American and nonNorth American journals. North American journals tend to be "particularly inward looking" (Tight, 2012a, 736). In contrast, journals outside the U.S. have internationalized vastly and rapidly in recent years.

\section{Methods}

We utilize critical discourse analysis (CDA), which centers on language as a form of social practice and how issues of power, equality, and dominance are reproduced in texts (Wodak 1995; van Dijk 2008). Through CDA, we analyze the discourse(s) present in scholarship on international higher education as well as consider how leading higher education journals shape discourse within this area of research.

\section{Search Procedures and Sample}

The data sources are articles published between 2000-2016 from four of the most highly indexed higher education journals. Two of these journals are U.S.-based (Journal of Higher Education, Research in Higher Education) and two are international (Higher Education, Studies in Higher Education). We selected these journals because of their strong reputation, indicating the powerful role they have in creating scholarly discourse within the field. We selected the timeframe to focus on contemporary discourse.

We use Knight's (2003) definition of the internationalization of higher education to guide our CDA, "Internationalisation at the national, sector, and institutional levels is defined as the process of integrating an international, intercultural, or global dimension into the purpose, functions or delivery of post-secondary education" (p. 2). This broad definition allowed us to 
develop a comprehensive literature search that fit within the scope of the study using a set of inclusion criteria. The use of inclusion/exclusion criterion reflects a purposive sampling technique, which aligns with the process of systematic inquiry (Saini and Shlonsky 2012). The inclusion criteria included articles that (1) were published in one of the four aforementioned journals (2) was published between 2010-2016 (3) could be retrieved by searching each of the journals' databases using 13 search terms (comparative higher education; internationalization; globalization; international development; cross-border; international partnerships; Global North; Global South; First World; Third World; developing countries; developed countries). This led to 887 articles being retrieved (Higher Education $=660$, Journal of Higher Education $=65$, Research in Higher Education = 125, Studies in Higher Education = 37). Next, we excluded article duplicates, book reviews, and editorials, which led to 43 manuscripts being removed. We then reviewed titles of the remaining 844 articles to ensure they focused on international higher education/internationalization of higher education. This led to 488 additional articles being excluded. Articles were removed if titles focused on the local context of one country's higher education system (e.g., historically underrepresented students in U.S. higher education, developing a research university in China) or emphasized higher education broadly with no mention of an international context (e.g., massification in universities, academic pedagogies). Next, we reviewed abstracts of the remaining 356 articles. This led to an additional 36 articles being excluded for lacking an international focus.

From the literature search, 320 articles were retrieved that met the inclusion criteria and focused on international higher education/internationalization of higher education. This includes 276 articles from Higher Education, 10 articles from Journal of Higher Education, 14 articles from Research in Higher Education, and 20 articles from Studies in Higher Education. 


\section{Data Analysis}

We first read each article and summarized the purpose, country context, year of publication, framework(s), methods (if applicable), and key findings. We also reviewed the websites of the four journals to capture the scope and nature of each. Next, we created a checklist that all team members used to analyze the articles' vocabulary, concepts used, and overall content. The checklist included questions such as: How does the article provide a critique of internationalization, international higher education, or globalization? How are concepts of power, privilege, domination, marginalization, hegemony, or inequality discussed at an organizational/institutional level? Does the article make recommendations for change that increases equity, diversity, or inclusivity? For each article, team members responded to each question, providing evidence from the article to support any claims made. Next, we considered how the individual articles within a journal created or was missing a common discourse that engaged criticality in international higher education. Team members wrote memos for each journal summarizing the overall discourse within the journal based upon the articles reviewed and the scope/nature of the journal. These memos were used to develop the findings for each journal. During this process, themes and patterns across the four journals also emerged.

\section{Findings}

The findings are organized by each of the four journals. Within each section, we present an overview of the scope of the journal regarding international higher education, the composition

of articles within the journal, an analysis of the articles' engagement with the topic of internationalization in higher education, and an analysis of the criticality of the articles. All overview information presented about the journals (e.g., scope, editorial board composition) is a cross-sectional snapshot of information captured in February or March of 2017. 


\section{Higher Education}

Higher Education has an international scope and encourages the submission of articles from all over the world (Springer 2015). Except for one coordinating editor and two advisory board members, all other editors and board members are from countries in the Global North, with over 50\% located in English speaking countries - U.S., U.K., Australia, and Canada (Springer n.da).

Composition of articles. We identified 276 articles from Higher Education. Regarding the geographic focus of the content of the articles, 63 covered countries in Asia, 63 covered European countries, 28 covered U.S. and Canada, and 16 covered Australia and New Zealand. Studies on countries in Latin America and Africa constituted 11 articles for each of these regions and seven articles focused on the Middle East. Although Asia had a large share of the articles, most of the research either focused on developed areas in Asia such as Japan, Singapore, Hong Kong, and South Korea (e.g., Jon, Lee and Byun 2014; Huang 2016) or emerging economies such as China and India (e.g., Feng 2013; Carnoy, Froumin, Loyalka and Tilak 2014). A noticeable trend was a rise in articles focusing on higher education in Asia, especially East Asia, in the last six years. Still, the majority of the articles in the journal focused on countries in the Global North and even when focusing on countries in the Global South, the articles often had a North-South comparison (e.g., McBurnie and Ziguras 2001; Marginson 2015).

Internationalization focus. The concept of internationalization is only explicitly defined in $10 \%$ of the articles. For example, Horn, Hendel, and Fry (2012) state that internationalization is a "multidimensional process permeating the instruction, research, service, and administrative activities of an institution in response to the complex challenges of globalization and an increasingly multicultural world" (163). Kauppinen (2012) defines internationalization in terms 
of different international activities such as study abroad programs, international student recruitment, staff mobility, establishment of branch campuses, and global partnerships between institutions. Although there was no uniform way in which authors defined the concept of internationalization, most described internationalization as a change process. For example, Teichler (2004) defines internationalization as "substantial changes in the context and inner life of higher education relative to an increasing frequency of border-crossing activities amidst a persistence of national systems" (22). Jones and Oleksiyenko (2011) call internationalization "a change process from a national HEI into an international HEI” (42). Finally, Yonezawa and Shimmi, (2015) view it as a "transformation of university governance" (176). Each of these definitions consider the internationalization of higher education to emphasize movement, change, and/or transformation, which all illustrate it as an active process, rather than a static goal.

Most articles concentrate on one or two aspects of internationalization such as student mobility (e.g., González, Mesanza and Mariel 2011; Paltridge, Mayson and Schapper 2014), cross-border or transnational education (e.g., Grange 2003; Wilkins and Huisman 2012) or international collaborations/partnerships (e.g., Hoffman et al. 2014). Some articles discuss internationalization by its affiliation with globalization and view it as a driver of changes within the national higher education system, such as increased marketization and the rise of private institutions (e.g., Mok 2005; Marginson 2007).

The most cited goal of higher education internationalization emphasized global competition and prestige (e.g., Slaughter and Cantwell 2012), closely followed by revenue generation and economic growth (e.g., Forbes-Mewett and Nyland 2013). A few discuss international cooperation, although these articles are mostly Europe-centric or emphasize NorthNorth research networks. For example, Teichler (2004) advocates for international collaborations 
and knowledge transfer and argues that while structural differences between nations can be a barrier to productive cooperation, they can also be beneficial. Teichler (2004) states, "they [international higher education collaborations] offer the opportunity for mobile and otherwise cooperating partners to learn from an environment which is in contrast from that at home" (18). However, his research focus is mostly on European countries, rather than more diverse collaborations across regions of the world. Improved quality of education and capacity building are also cited goals of internationalization, especially when focusing on transnational or crossborder education (e.g., McBurnie and Ziguras 2001; Grange 2003).

Criticality of articles. Of the 276 articles analyzed, 102 used a critical lens or framework to engage international higher education issues. These articles emphasized diverse themes including the neoliberal influence on education policies and subsequent marketization and privatization of higher education (e.g., Polster 2000; Ding and Levin 2007), unequal access to college (e.g., Horie 2002), and the role of international organizations in perpetuating an ideology that does not acknowledge the cultural and historical context of a country's higher education system (e.g., Kempner and Loureiro 2002; Välimaa and Nokkala 2014). For example, Polster (2000) criticizes government and institutional policies that encourage academics to seek patents and produce knowledge that serves the corporate interest, rather than the public interest. Collins and Rhodes (2010) are critical of the neoliberal and neocolonial influence of the World Bank in reproducing wealthy nations' hegemony through higher education policies. Similarly, Kempner and Loureiro (2002) critique international agencies for treating all developing countries in the same way and applying the same solutions in an effort to solve their problems. Grange (2003) suggests that international higher education partnerships can be likened to a form of colonization that has the more influential partner pushing its own agenda. Most of these articles critique issues 
at a country/regional or institutional level and generally examines the inequalities perpetuated by the global market in higher education (e.g., Kempner and Loureiro 2002), the predominance of English language (e.g., Torres-Olave, 2012), and how power differences benefit some countries' higher education systems, but not others (e.g., Marginson 2007).

A major theme within the critically-focused articles was the hegemony of neoliberal discourse. Some scholars named neo-liberalism as a tool to maintain the status quo amongst nations and within countries, criticizing the role supranational organizations play in implementing education policies, such as privatization of higher education, which favor the interests of the capitalist class and perpetuates inequalities (e.g., Torres and Schugurensky, 2002; Collins and Rhoads, 2010). However, not all articles containing the neoliberal framework are critical in nature. Some discuss neoliberalism and marketization, but there is an absence of discussion around equality and access to higher education. For example, while Buckner (2016) claims to apply a cultural lens to her analysis, there is no mention of the role that race and class play in developing the culture that leads to a particular worldview regarding higher education. Similarly, Lo (2016) discusses neoliberalism but does not talk about interests, agendas, or who benefits and who is marginalized from such an ideology.

\section{Journal of Higher Education}

The Journal of Higher Education publishes scholarship from "a wide variety of theoretical perspectives and disciplinary orientations" (Taylor \& Francis Online, 2017a). Although it welcomes comparative and international scholarship, it requires these articles to have "clear connections to the U.S. context" (Taylor \& Francis Online, 2017a). In line with this U.S. focus, the editorial board consists of scholars from only U.S. universities. 
Composition of articles. We identified 10 articles from the Journal of Higher Education. Although the journal is U.S.-focused, only two articles on international higher education solely focused on the U.S. context (Zhao, Kuh and Carini 2005; Kim, Wolf-Wendel and Twombly 2011). The rest included non-U.S. higher education systems as a comparative context of which two focused on Canada (Davies and Hammack 2005; Metcalfe 2010), one on Australia (Marsh, Rowe and Martin 2002), and one on Europe (Huisman, Weert and Bartelese 2002). Four articles did not focus on a specific country context, but discussed internationalization broadly (e.g., Scott 2006; Walker 2009). Only the four articles that focused on internationalization broadly also consider countries in the Global South. For example, Marginson (2016) compares the world's largest nations (by population) on the proportion of their population living in urban areas and their gross tertiary enrollment ratio. Thereby this article discussed countries in all parts of the world.

Internationalization focus. Only four of the ten articles explicitly define internationalization in higher education. The authors of these articles discuss internationalization as a process of increasing interdependence between countries. For example, Ayers and Palmadessa (2015) state, “Today’s dominant social imaginary reflects an increasing sense of global interdependence” (864). Similarly Scott (2006) mentions interdependence, “The 21st century is rapidly heading toward a globalization stage. As the body of nation-states becomes increasingly interdependent, another university mission is arising" (6).

There was a difference in how internationalization was discussed in articles that engaged a critical lens versus articles that did not. For example, in articles that used a critical lens, internationalization is framed in terms of how it creates challenges. Ayers and Palmadessa 
(2015) discuss the concept of global interdependence and immediately connect this definition to the problems that result from this process:

Today’s dominant social imaginary reflects an increasing sense of global interdependence, which raises complex problems for policy actors embedded within local, state, or national policy making bodies. (864)

Additionally, Walker (2009) reflects on internationalization by highlighting the role of time, "academic capitalism is premised on faculty and students both justifying their use of time and seeking to outsmart it" (Walker 2009, 485). Walker (2009) states that previous research on the internationalization of higher education focused on the changing demands of the knowledge economy and less on the "temporal ramifications of global capitalism" (484). To gain a better understanding of how globalization impacts higher education, she argues, it is essential to take into consideration the role of time in academic capitalism.

Criticality of articles. Of the ten articles, four used a critical lens to examine the internationalization of higher education. The other articles examine internationalization as a process, but refrain from stating how this process is disadvantaging some and privileging others. While the exportation of the American university model was widely discussed, only the four critical articles questioned the assumed positive impact of adopting the American model of higher education. For example, Scott (2006) questions the desirability of using the American model and whether internationalization is beneficial to the local context.

Another theme across the critical articles is whether universities exhibit autonomy in their organization and administration. For example, Ayers and Palmadessa (2015) argue that community colleges have "appropriated a discourse in which economic activity at the global scale transcends regulation, the nation-state lacks the moral authority to influence markets, and 
local communities are forced to adapt" (867). Thus, suggesting that community colleges are controlled by global market systems. While the six less critically-centered articles seem to accept the process of internationalization and how it shapes higher education, in the other four articles, a clear critique is made regarding global processes and the local communities that are subjected to these global processes.

Additionally, the four more critically-centered articles illustrated how institutions were impacted by neo-liberalism and global capitalism. For example, Walker (2009) states that international higher education research is mostly centered on institutions, and less so on the influence of global capitalism,

While researchers in higher education have sought to understand how globalization impacts upon academia, they have tended to focus less on the temporal ramifications of global capitalism. Instead, the focus has generally been on how the changing demands of the knowledge economy affect the character and purpose of higher education institutions.

Walker shows in her analysis that concepts of power, privilege, domination, marginalization, hegemony, and inequality in higher education become apparent when discussed on a global level.

The four critical articles also discussed inequality and marginalization on an individual level. However, while these articles touched upon some of the implications for individual students (e.g., Marginson 2016) and faculty (e.g. Ayers and Palmadessa 2015), no clear recommendations were made as to how to engage in specific actions that would lessen negative outcomes related to the internationalization of higher education on individuals.

\section{Research in Higher Education}


Research in Higher Education provides an invitation for "studies outside the United States that are of interest to the readership" (Springer, n.db). Of the forty-one members of the journal's review board, thirty-seven represent U.S.-based universities (Springer, n.dc).

International board members represent the countries of Macau, Oman, Taiwan, and Zimbabwe.

Composition of articles. Our literature search rendered 14 articles. Ten had a U.S. or Western Europe focus (e.g., Garcia-Aracil 2008; Luo and Jamieson-Drake 2015). Three of the four articles represented countries in the Global South, including: Chile (Farías and Sevilla, 2015), Lebanon (McCabe, Feghali and Abdallah 2008), and Malaysia (Shafaei and Razak 2016). One article was a bibliographic map of research on international higher education, representing countries around the world (Kuzhabekova, Hendel and Chapman 2015).

Internationalization focus. Although many of the articles reviewed referenced internationalization in the narrative, there were no articles that specifically defined either this term. However, higher education was frequently referred to, directly and indirectly, as a globally competitive marketplace and a modern day reality suitable for discussion and attention.

Many of the articles lacked concrete recommendations for future research or practice with respect to the broader impact of internationalization on higher education. For example, Kuzhabekova et al. (2015) recommend increased research beyond individual country borders to remain competitive in a global marketplace, but stop short of offering any tangible steps for researchers or methods by which to consider cross-national research. Additionally, Mamiseishvili and Rosser (2010) suggest U.S. institutions are not fully recognizing the talents of international faculty and should promote inclusivity. Yet the authors do not provide any concrete steps for how an institution can endeavor to attract more international faculty. 
Criticality of articles. Only three articles approached the topic of internationalization of higher education with a critical lens. For example, Taylor and Cantwell (2015) discuss the impact of internationalization on the U.S. and the challenges associated with global competition for students. Each of the three articles also paid specific attention to the local country context with respect to the impact of internationalization on the higher education system.

Shafaei and Razak (2016) take perhaps the most critical view of internationalization in their discussion of the internal struggle of international postgraduate students regarding ethnic identity and the host society. The article focuses on how perceived stereotypes influence psychological and sociocultural adaptation of identity. It underscores the need to consider factors related to cross-cultural adaptation for international students as well as the unanticipated impacts of internationalization in higher education.

\section{Studies in Higher Education}

Studies in Higher Education is described on its website as "a leading international journal" in the field of higher education (Taylor \& Francis Online, 2017b). Regional representations in the editorial advisory board is broad; nine members have institutional affiliations in Europe, four in Asia, two in Africa, three in North America, two in Australia/ Oceania, and one in South America (Taylor \& Francis Online, 2017c).

Composition of articles. Twenty articles were identified from Studies in Higher Education. Articles focused on higher education systems from around the world: Taiwan, Sweden, Australia, Malaysia, Singapore, South Africa, Brazil, Spain, Cyprus, Germany, Sweden, the United States, and Canada. However, most countries represented reflected the Global North.

Internationalization focus. Internationalization, while often central to these articles, was widely interpreted. Traditional definitions, such as student mobility and international projects, 
were often rooted in Canada-based scholar Jane Knight's $(2003 ; 2008)$ definition of internationalization (e.g., Tadaki and Tremewan, 2013; Hou 2014), and interpreted as a positive force to improve societies and economies (Rumbley, Stanfield and de Gayardon 2014). Internationalization and international higher education were also defined as: a form of trade or export (Blackmore 2009; Smith 2014); de-regulation and marketization (Hemsley-Brown 2013); Westernization (Powell and Solga 2010); competition (Postiglione 2013); and the East-West transfer of students (Wang Harding and Mai 2012).

Of articles that made recommendations to increase global engagement and equity, recommendations were often broad and vague, lacking tangible next steps for future researchers and practitioners. This was evidenced at the individual, institutional, regional, and international levels (e.g, Papastephanou 2005; Postiglione 2013; Rumbley et al. 2014). For example, Papastephanou (2005), recommends critical thinking and involved educators to combat elitist higher education trends, but provides no details on how this can be thoughtfully adapted to classrooms for educators. Rumbley et al. (2014) suggest that "connecting peers of researchers and educators" (1294) can increase knowledge transmission and promote improved cross-border collaborations, yet fails to explain how this might be achieved.

Criticality of articles. Of the 20 articles, half used a critical lens. This divide appears to reflect geographic lines. For example, researchers with Western institutional affiliation (U.S., U.K., Australia, and Canada), as well as Hong Kong were often authors on articles without a critical lens. More critical articles conversely represented authors with a much broader geographic spread in terms of institutional affiliation including Malaysia, Singapore, South Africa, Brazil, Cyprus, Spain, Sweden, and Germany. 
Articles that were less critical-focused either failed to explore power dynamics within international higher education or suggested the presence of a power imbalance, but did not directly explore it. For example, at the individual level Wang et al. (2012) advocate for international student adaptation in Western institutions. At the regional level, Postiglione (2013) suggest the successes of Hong Kong universities, when compared to mainland China, were in part the result of modeling their system after Western styles of education, but failed to explore this as a potentially hegemonic influence. Smith (2014) evaluated the experiences of Western faculty in non-Western universities, but failed to acknowledge the ways in which gender and Western status shape those experiences.

More critical articles often critiqued neo-liberalism (e.g., Blackmore 2009), the commodification of higher education (e.g., Hill, Cheong, Leong and Fernandez-Chung 2014), and the influence of Western higher education on the rest of the world (e.g., Powell and Solga, 2010; Doiz, Lasagabaster and Sierra 2013). Blackmore (2009), for example, was highly critical of the role neo-liberalism and marketization play in higher education since it, "assumes and encourages the view that students know what they want" (860), elevating student course evaluations while marginalizing teachers whose professions are being reduced to measurable outputs. Hill et al. (2014) describe transnational education as a commodity, while critically exploring the continued preference in Malaysian universities towards UK institutions. Additionally, Doiz et al. (2013) consider hegemony through the homogenization of English in the Basque Country and throughout the world, and its threat to "linguistic diversity" (1419).

\section{Discussion}

The four journals that we investigated have a strong reputation in higher education research, which allows them to influence discourses shaping the field. Our analysis focused on 
how these journals portray internationalization in higher education through the articles they publish. We specifically focused on whether and how these articles utilized a critical lens that would bring issues of power and equity to the forefront. Our analysis revealed themes across the journals and articles.

The first is a strong Western focus across all four journals in terms of institutional affiliations of editorial boards and authors as well as the geographic orientation of the articles' content. For example, $89 \%$ of the members of editorial boards across the journals have institutional affiliations from the United States, Europe, Canada or Australia/New Zealand. The dominance of Western scholars within journal leadership has subsequent consequences for journal content as Murphy and Zhu (2012) explain in their study of neo-colonialism in academic journals, "editorial boards are at the strategic center of the journal community; they influence the interests of the journal, the networks of reviewers, the selection of special issue topics, etc." (924). The authors argue that by diversifying editorial boards, there would be a "cascading effect" that would create greater diversity and inclusiveness in published articles' authors and content (Murphy and Zhu 2012).

While slightly more diverse, there is still a narrowed geographic affiliation of first authors within the four journals (72\% from U.S., Canada, Europe, Australia/New Zealand). In Studies in Higher Education, we found that authors using a more critical lens in their research were more often from non-Western institutions. While we cannot assert causation, other scholars have similarly found limited engagement with critical or alternative frameworks within North American higher education journals (Tight 2007) and within top-tier higher education journals (Tight 2012b). Tight (2012b) explains, 'higher education research can be rather 'conservative' in its approach - more concerned with practices and their improvement, rather than with seeking to 
challenge the underlying structures and advance alternative positions” (192). Furthermore, although the massification and internationalization of higher education is expanding options for tertiary education throughout the world (Zeleza 2012), we saw less than one-third of articles focused on non-Western nations. When non-Western nations were disaggregated, most were still developed nations. The lack of representation of research focused on non-Western, nondeveloped countries or published by researchers from these regions may reflect a larger centerperiphery dynamic within higher education. Altbach, Reisberg, and Rumbley (2009) argue that universities globally are characterized by either being at the center or periphery based upon factors such as rankings, quality, research production, and wealth. North American and European universities are often considered at the center and are treated as academic models throughout the world (Altbach et al. 2009). The geographic composition of editorial boards, authors, and content of articles reviewed in this study appear to parallel this dynamic. Thus, placing non-Western and non-developed nations at the periphery in terms of their representation in research.

The concept of internationalization is complex and challenging to define within higher education given the need for researchers to apply it to diverse country contexts and university systems (Knight 2003). While we selected articles for their focus on internationalization within higher education, we found that the majority of articles did not explicitly define internationalization. When articles did describe the concept, it was often discussed as a change process within higher education that can positively improve universities. However, articles that had a more critical emphasis did tend to illustrate how internationalization could foster both positive and negative outcomes for higher education institutions, while less critical articles tended to emphasize solely the positive. For example, a major theme in how internationalization was discussed within articles was as a force that better positioned higher education within the 
global marketplace and that created greater prestige for individual universities. Yet, articles with a critical lens would also often critique this outcome as a driver of neo-liberalism that weakens the role of higher education as a public good. One reason for this distinction may align with Brandenburg and de Wit's (2011) argument that the goal of internationalization within higher education has become the standard or norm, rather than an innovation. Thus, scholarship using a critical lens (which seeks to challenge the status quo) would in turn be more likely to challenge the "new normal" of internationalization as having predominantly beneficial outcomes.

Additionally, while all of the journals tended to have articles focused broadly on macro-level systems (e.g., region, nation, institution), articles with a critical lens more often also focused on micro-level systems such as unequal power dynamics for individuals within an institution or the impact of initiatives on the local community context.

Although education is an applied field, across journals we found that implications for practice lacked specificity. This is a particularly important finding for articles that were more critical in nature, given that a critical worldview is change-oriented and action-focused (Crotty 1998). While implications in these articles called for social change and greater equity in educational systems and power structures, authors often did not provide concrete action steps for engaging in recommended practices. Higher education scholarship has been criticized for its lack of emphasis on practical application and a disconnect between theory/research and practice (Bensimon 2007; Reason and Kimball 2012). Because the journals we analyzed are traditional research outlets, they may be less concerned with the application of findings. However, we argue that the expectation of including explicit and comprehensive implications for action should be invoked, particularly for articles engaging a critical worldview, given the transformative nature and purpose of that paradigm. 


\section{Implications}

The journals we investigated help set the tone for what is deemed valuable and relevant higher education research. Yet, the articles we analyzed frequently failed to address power and hegemony that are embedded in existing higher education systems and partnerships, and it is prudent for editorial boards to hold themselves and their authors accountable to acknowledging and addressing such issues in our field. We believe editorial boards should make greater effort to add critical components to the scope of their respective journals, or perhaps have a special issue dedicated to critical issues in international higher education. To this end, we recognize the important role that reviewers play as gatekeepers of published research. Reviewers and members of editorial boards, including the authors of this article, need to recognize our roles in either reinforcing or interrupting Western epistemic dominance through our service activities. Stein (2017) argues eloquently that contemporary educational institutions are based on a colonial/modern imaginary. Such imaginary determines not only what is valuable and desirable, from a peer-review perspective, but also what is possible (Stein \& Andreotti, 2017). Authors, reviewers, and editors may need to reflect on our assumptions of what counts as knowledge and the origins of these assumptions.

Given the narrow geographic representation of articles across journals, we recommend editors make greater effort to include authors and articles from underrepresented regions. For example, providing a special issue focusing on specific regions would highlight parts of the world that are underrepresented in these journals. Additionally, training editorial board members and reviewers to be more conscientious of submissions from scholars for which English is not the primary language may help address disparities in regional representation. 
Rather than contributing to the divide between research and practice, we urge editorial boards to encourage authors to make clearer connections to the practical implications of their research and, as appropriate, provide recommendations correlated to their research results. Although this ultimately is the responsibility of the author(s), the editorial board is responsible for establishing publication guidelines and setting a journal's tone.

Based on the findings of this study, we suggest that scholars move beyond using internationalization as a buzzword and start using explicit definitions of this concept. The term internationalization has become a loaded term that is often poorly defined (Brandenburg and de Wit 2011). By explicitly defining it, authors will demonstrate the complexity of the concept as well as clarify assumptions associated with it, enabling a more specific and thoughtful analysis of internationalization and its impact.

Lastly, we suggest authors dedicate more space to describing how their findings inform higher education policy and action. Though the more critical scholarship took into consideration both the global and individual implications of internationalization, they often remained vague about policy implications or what action is required. The need for stronger implications for policy and practice may require collaboration between scholars and practitioners, non-academics and research participants. Recommendations for action, however, can be reimagined in ways that go beyond policy recommendations; we also need to identify actions of resistance, healing, organizing, and imagining (e.g. Shahjahan, 2014; Shahjahan et al., 2017). This can create better understanding of the context in which internationalization and injustice take place and inform research practice that is meaningful to current higher education systems. 


\section{References}

Altbach, P., Reisberg, L. and Rumbley, L. 2009. Trends in Global Higher Education: Tracking an Academic Revolution. Paris, France: UNESCO.

Ayers, D. and Palmadessa, A. 2015. "The Community College and a Rising Global Imaginary: An Analysis of Practical Reasoning, 1950-2013.” The Journal of Higher Education, 86 (6): 864-892.

Baez, B. 2007. “Thinking Critically About the 'Critical' Quantitative Research as Social Critique." New directions for institutional research, 133: 17-23.

Bensimon, E. 2007. “The Underestimated Significance of Practitioner Knowledge in the Scholarship on Student Success.” The Review of Higher Education, 30 (4): 441-469.

Blackmore. J. 2009. “Academic Pedagogies, Quality Logics and Performative Universities: Evaluating Teaching and What Students Want." Studies in Higher Education, 34 (8): $857-872$.

Brandenburg, U. and de Wit, H. 2011. "The End of Internationalization.” International Higher Education, 62: 15-17.

Buckner, E. 2016. "The Changing Discourse on Higher Education and the Nation-State, 19602010." Higher Education, 1-17.

Carnoy, M., Froumin, I., Loyalka, P., and Tilak, J. 2014. "The Concept of Public Goods, the State, and Higher Education Finance: A View from the BRICs.” Higher Education, 68 (3): $359-378$.

Collins, C. and Rhoads, R. 2010. "The World Bank, Support for Universities, and Asymmetrical Power Relations in International Development.” Higher Education, 59 (2): 181-205. 
Crotty, M. 1998. The Foundations of Social Research: Meaning and Perspective in the Research Process. London: Sage.

Davies, S., and Hammack, F. 2005. "The Channeling of Student Competition in Higher Education: Comparing Canada and the US." The Journal of Higher Education, 76 (1): 89-106.

Ding, A. and Levin, S. 2007. "The Interventionary State in China and Programs and Curricula at a Chinese Vocational University." Higher Education, 53 (5): 539-560.

Doiz, A., Lasagabaster, D., and Sierra, J. 2013. “Globalisation, Internationalisation, Multilingualism and Linguistic Strains in Higher Education.” Studies in Higher Education, 38 (9): 1407-1421.

Easton, P. 2014. "Documenting the Evolution of the Field: Reflections on the 2013 Comparative Education Review Bibliography." Comparative Education Review, 58 (4): 555-574.

Farías, M. and Sevilla, M. 2015. 'Effectiveness of Vocational High Schools in Students' Access to and Persistence in Postsecondary Vocational Education." Research in Higher Education, 56 (7): 693-718.

Feng, Y. 2013. 'University of Nottingham Ningbo China and Xi'an Jiaotong-Liverpool University: Globalization of Higher Education in China.” Higher Education, 65 (4): 471485.

Forbes-Mewett, H. and Nyland, C. 2013. "Funding International Student Support Services: Tension and Power in the University." Higher Education, 65 (2), 181-192.

Garcia-Aracil, A. 2008. “College Major and the Gender Earnings Gap: A Multi-Country Examination of Postgraduate Labour Market Outcomes." Research in Higher Education, 49 (8): 733-757. 
Giroux, H. 2011. On Critical Pedagogy. London: Bloomsbury.

González, C., Mesanza, R., and Mariel, P. 2011. "The Determinants of International Student Mobility Flows: An Empirical Study on the Erasmus Programme.” Higher Education, 62 (4): 413-430.

Grange, L. 2003. "The Role of (Dis)trust in a (Trans)national Higher Education Development Project." Higher Education, 46 (4): 491-505.

Guba, E. and Lincoln, Y. 1994. “Competing Paradigms in Qualitative Research.” In Handbook of qualitative research, ed. N. K. Denzin and Y. S. Lincoln. London: Sage.

Hemsley-Brown, J. 2013. “'The Best Education in the World': Reality, Repetition or Cliché? International Students' Reasons for Choosing an English University.” Studies in Higher Education, 38 (2): 1005-1022.

Hill, C., Cheong, K., Leong, Y., and Fernandez-Chung, R. 2014. “TNE-Trans-national Education or Tensions Between National and External? A Case Study of Malaysia.” Studies in Higher Education, 39 (6): 952-966.

Hoffman, D., Blasi, B., Ćulum, B., Dragšić, Ž., Ewen, A., Horta, H., .. Rios-Aguilar, C. 2014. “The Methodological Illumination of a Blind Spot: Information and Communication Technology and International Research Team Dynamics in a Higher Education Research Program." Higher Education, 67 (4): 473-495.

Horie, M. 2002. "The Internationalization of Higher Education in Japan in the 1990s: A Reconsideration." Higher Education, 43 (1): 65-84.

Horn, A., Hendel, D. and Fry, G. 2012. “The Empirical Basis for Adopting a Civic Rationale for Internationalization." Higher Education, 64: 161-175. 
Huang, F. 2016. “The Impact of Mass and Universal Higher Education on Curriculum and Instruction: Case Studies of China and Japan.” Higher Education, 1-19.

Huisman, J., de Weert, E., and Bartelse, J. 2002. “Academic Careers from a European Perspective: The Declining Desirability of the Faculty Position." The Journal of Higher Education, 73 (1): 141-160.

Jon, J., Lee, J. and Byun, K. 2014. "The Emergence of a Regional Hub: Comparing International Student Choices and Experiences in South Korea.” Higher Education, 67 (5): 691-710.

Jones, G. and Oleksiyenko, A. 2011. "The Internationalization of Canadian University Research: A Global Higher Education Matrix Analysis of Multi-level Governance.” Higher Education, 61 (1): 41-57.

Kauppinen, I. 2012. "Towards Transnational Academic Capitalism.” Higher Education, 64 (4): $543-556$.

Kempner, K. and Loureiro, A. 2002. "The Global Politics of Education: Brazil and the World Bank." Higher Education, 43 (3): 331-354.

Kim, D., Wolf-Wendel, L. and Twombly, S. 2011. "International Faculty: Experiences of Academic Life and Productivity in US Universities." The Journal of Higher Education, 82 (6): 720-747.

Knight, J. 2003. "Updating the Definition of Internationalization.” International Higher Education, 33 (fall): 2-3.

Knight, J. 2008. Higher Education in Turmoil: The Changing World of Internationalization. Rotterdam: Sense.

Kuzhabekova, A., Hendel, D. and Chapman, D. 2015. "Mapping Global Research on International Higher Education." Research in Higher Education, 56 (8): 861-882. 
Lo, W. 2016. "The Recalibration of Neoliberalisation: Repoliticising Higher Education Policy in Hong Kong." Higher Education, 1-15.

Luo, J. and Jamieson-Drake, D. 2015. "Predictors of Study Abroad Intent, Participation, and College Outcomes." Research in Higher Education, 56 (1): 29-56.

Mamiseishvili, K. and Rosser, V. 2010. "International and Citizen Faculty in the United States: An Examination of Their Productivity at Research Universities." Research in Higher Education, 51 (1): 88-107.

Marginson, S. 2007. "The Public/Private Divide in Higher Education: A Global Revision.” Higher Education, 53 (3): 307-333.

Marginson, S. 2015. "The Strategic Positioning of Australian Research Universities in the East Asian Region.” Higher Education, 70 (2): 265-281.

Marginson, S. 2016. "High Participation Systems of Higher Education.” The Journal of Higher Education, 87 (2): 243-271.

Marsh, H., Rowe, K. and Martin, A. 2002. 'PhD Students' Evaluations of Research Supervision: Issues, Complexities, and Challenges in a Nationwide Australian Experiment in Benchmarking Universities.” The Journal of Higher Education, 73 (3): 313-348.

Metcalfe, A. (2010). "Revisiting Academic Capitalism in Canada: No Longer the Exception." The Journal of Higher Education, 81 (4): 489-514.

McBurnie, G. and Ziguras, C. 2001. "The Regulation of Transnational Higher Education in Southeast Asia: Case studies of Hong Kong, Malaysia and Australia." Higher Education, 42 (1): 85-105.

McCabe, D., Feghali, T., and Abdallah, H. 2008. "Academic Dishonesty in the Middle East: Individual and Contextual Factors.” Research in Higher Education, 49 (5): 451-467. 
Mok, K. 2005. "Globalization and Educational Restructuring: University Merging and Changing Governance in China." Higher Education, 50 (1): 57-88.

Murphy, J. and Zhu, J. 2012. "Neo-colonialism in the Academy? Anglo-American Domination in Management Journals.” Organization, 19 (6): 915-927.

Paltridge, T., Mayson, S. and Schapper, J. 2014. "Welcome and Exclusion: An Analysis of the Australian Newspaper's Coverage of International Students.” Higher Education, 68: 103116.

Papastephanou, M. 2005. 'Difference-sensitive Communities, Networked Learning, and Higher Education: Potentialities and Risks." Studies in Higher Education, 30 (1): 81-94.

Polster, C. 2000. "The Future of the Liberal University in the Era of the Global Knowledge Grab. Higher Education, 39 (1): 19-41.

Postiglione, G. 2013. “Anchoring Globalization in Hong Kong's Research Universities: Network Agents, Institutional Arrangements, and Brain Circulation." Studies in Higher Education, 38 (3): 345-366.

Powell, J. and Solga, H. 2010. “Analyzing the Nexus of Higher Education and Vocational Training in Europe: A Comparative-Institutional Framework.” Studies in Higher Education, 35 (6): 705-721.

Pring, R. 2000. “The 'False Dualism' of Educational Research.” Journal of Philosophy of Education, 34 (2): 247-260.

Raby, R. 2007. "Fifty Years of Comparative Education Review Bibliographies: Reflections on the Field." Comparative Education Review, 51 (3): 379-398. 
Reason, R. and Kimball. E. W. (2012). “A New Theory-to-Practice Model for Student Affairs: Integrating Scholarship, Context, and Reflection.” Journal of Student Affairs Research and Practice, 49 (4): 359-376.

Rumbley, L., Stanfield, D. and de Gayardon, A. 2014. "From Inventory to Insight: Making Sense of the Global Landscape of Higher Education Research, Training, and Publication.” Studies in Higher Education, 39 (8): 1293-1305.

Saini, M. and Shlonsky, A. 2012. Systematic Synthesis of Qualitative Research. New York: Oxford University Press.

Scott, J. 2006. "The Mission of the University: Medieval to Postmodern Transformations." The Journal of Higher Education, 77 (1): 1-39.

Shafaei, A. and Razak, N. 2016. 'International Postgraduate Students' Cross-Cultural Adaptation in Malaysia: Antecedents and Outcomes." Research in Higher Education, 57 (6): 739-767.

Shahjahan, R. 2014. From 'No'to 'Yes': Postcolonial Perspectives on Resistance to Neoliberal Higher Education. Discourse: Studies in the Cultural Politics of Education, 35(2), pp.219-232.

Shahjahan, R., Blanco Ramirez, G. and Andreotti, V., 2017. Attempting to Imagine the Unimaginable: A Decolonial Reading of Global University Rankings. Comparative Education Review, 61(S1), pp.51-73.

Shahjahan, R. and Kezar, A. 2013. 'Beyond the 'National Container': Addressing Methodological Nationalism in Higher Education Research.” Educational Researcher, 42 (1): 20-29.

Slaughter, S. and Cantwell, B. 2012. "Transatlantic Moves to the Market: The United States and 
the European Union.” Higher Education, 63 (5): 583-606.

Smith, K. 2014. "Exploring Flying Faculty Teaching Experiences: Motivations, Challenges and Opportunities." Studies in Higher Education, 39 (1): 117-134.

Springer. 2015. Journal of Higher Education: Journal Metrics 2015. http://static.springer.com/sgw/documents/1592324/application/pdf/10734_Journal\%2520 Metrics_2015_flyer\%5B1\%5D.pdf. Accessed 02 March 2017.

Springer. nd.a. Journal of Higher Education Editorial Board. http://www.springer.com/education+\%26+language/higher+education/journal/10734?det ailsPage=editorialBoard. Accessed 02 March 2017.

Springer. nd.b. Research in Higher Education Aims and Scope. http://www.springer.com/education+\%26+language/higher+education/journal/11162 Springer. nd.c. Research in Higher Education Editorial Board. http://www.springer.com/education+\%26+language/higher+education/journal/11162?det $\underline{\text { ailsPage }=\text { editorialBoard }}$

Stein, S., 2017. "The Persistent Challenges of Addressing Epistemic Dominance in Higher Education: Considering the Case of Curriculum Internationalization." Comparative Education Review, 61 (S1): 25-50.

Stein, S. and Andreotti, V. 2017. "Higher Education and the Modern/Colonial Global Imaginary." Cultural Studies $\leftrightarrow$ Critical Methodologies, 17 (3): 173-181.

Tadaki, M. and Tremewan, C. 2013. "Reimagining Internationalization in Higher Education: International Consortia as a Transformative Space?” Studies in Higher Education, 38 (3): $367-387$.

Taylor, B. and Cantwell, B. 2015. "Global Competition, US Research Universities, and 
International Doctoral Education: Growth and Consolidation of an Organizational Field." Research in Higher Education, 56 (5): 411-441.

Taylor \& Francis Online. 2017a. Journal of Higher Education Aims and Scope. http://www.tandfonline.com/action/journalInformation?show=aimsScope\&journalCode= uhej20. Accessed 02 March 2017.

Taylor \& Francis Online, 2017b. Studies in Higher Education Aims and Scope. http://www.tandfonline.com/action/journalInformation?show=aimsScope\&journalCode= cshe 20

Taylor \& Francis Online, 2017c. Studies in Higher Education Editorial Board. http://www.tandfonline.com/action/journalInformation?show=editorialBoard\&journalCo $\mathrm{de}=\mathrm{cshe} 20$

Teichler, U. 2004. “The Changing Debate on Internationalisation of Higher Education.” Higher Education, 48 (1): 5-26.

Tight, M. 2007. "Bridging the Divide: A Comparative Analysis of Articles of Higher Education Journals Published inside and outside North America." Higher Education, 53 (2): 235253.

Tight, M. 2012a. "Higher Education Research 2000-2010: Changing Journal Publication Patterns." Higher Education Research \& Development, 31 (5): 723-740.

Tight, M. 2012b. Researching Higher Education. 2nd ed. Maidenhead: Open University Press.

Tight, M. 2013. "Discipline and Methodology in Higher Education Research.” Higher Education Research \& Development, 32 (1): 136-151.

Tight, M. 2014. "Working in Separate Silos? What Citation Patterns Reveal about Higher Education Research Internationally.” Higher Education 68 (3): 379-395. 
Tikly, L. and Bond, T. 2013. "Towards a Postcolonial Research Ethics in Comparative and International Education." Compare: A Journal of Comparative and International Education 43 (4): 422-442.

Torres, C. and Schugurensky, D. 2002. "The Political Economy of Higher Education in the Era of Neoliberal Globalization: Latin America in Comparative Perspective.” Higher Education, 43 (4): 429-455

Torres-Olave, B. 2012. “Imaginative Geographies: Identity, Difference, and English as the Language of Instruction in a Mexican University Program.” Higher Education, 63 (3): $317-335$.

Välimaa, J. and Nokkala, T. 2014. "The Dimensions of Social Dynamics in Comparative Studies on Higher Education." Higher Education, 67 (4): 423-437.

van Dijk, T. 2008 “Critical Discourse Analysis.” In The Handbook of Discourse Analysis, eds. D. Schiffrin, D. Tannen and H. Hamilton. Malden, MA: Blackwell.

Walker, J. 2009. "Time as the Fourth Dimension in the Globalization of Higher Education." The Journal of Higher Education, 80 (5): 483-509.

Wang, Y., Harding, R. and Mai, L. 2012. "Impact of Cultural Exposure on Young Chinese Students' Adaptation in a UK Business School." Studies in Higher Education, 37 (5): 621-639.

Wilkins, S., and Huisman, J. 2012. “The International Branch Campus as Transnational Strategy in Higher Education.” Higher Education, 64 (5): 627-645.

Wodak, R. 1995. "Critical Linguistics and Critical Discourse Analysis.” In Handbook of Pragmatics: Manual, eds. J. Verschuren, J. Ostman, and J. Blommaert. Philadelphia: John Benjamins. 
Yonezawa, A. and Yukiko S. 2015. "Transformation of University Governance through Internationalization: Challenges for Top Universities and Government Policies in Japan." Higher Education 70 (2): 173-186.

Zeleza, P. 2012. "Internationalisation in Higher Education: Opportunities and Challenges for the Knowledge Project in the Global South.” In Internationalisation in Higher Education: Perspectives from the Global South, ed. P. Kotecha. Wits, South Africa: SARUA.

Zhao, C. Kuh, G. and Carini, R. 2005. "A Comparison of International Student and American Student Engagement in Effective Educational Practices." The Journal of Higher Education, 76 (2): 209-231. 